\title{
ІСТОРІЯ ОСВІТИ
}

DOI 10.33930/ed.2019.5007.27(10)-4

УДК 37.031:373.3(09)(477)“1991-2001”

ТЕНДЕНЦЇ̈ РОЗВИТКУ ПІДРУЧНИКОТВОРЕННЯ В ПОЧАТКОВІЙ ОСВІТІ В ПЕРШЕ ДЕСЯТИЛІТТЯ ДЕРЖАВНОї НЕЗАЛЕЖНОСТІ УКРАЇНИ (1991-2001)

\author{
TRENDS IN THE DEVELOPMENT OF TEXTBOOK CREATION IN THE \\ PRIMARY EDUCATION IN THE FIRST DECADE OF STATE \\ INDEPENDENCE OF UKRAINE (1991-2001)
}

\section{Т. Л. Гавриленко Г. М. Розлуцька}

Актуальність теми дослідження. В умовах створення Нової украӥнської школи важливого значення набувае модернізація змісту освіти, одним із засобів реалізацї якого був $i$ залишається підручник. Відтак завданням науковиів $i$ педагогів-практиків $\epsilon$ підготовка навчальної літератури нового покоління.

\section{Постановка}

проблеми. Нинішні освітні трансбормациї актуалізують грунтовне вивчення, осмислення $i$ творче використання вітчизняного історико-педагогічного досвіду, зокрема розвитку підручникотворення в початковій освіті. $\mathrm{y}$ такому контексті наукове зацікавлення викликає період відродження національної школи в Украйні, характерними особливостями якого стало суттеве оновлення змісту початкової освіти, створення нового покоління підручників для молодших школярів.

Аналіз останніх досліджень $\boldsymbol{i}$ публікацій. Різні аспекти розвитку підручникотворення в початковій освіті в обраних хронологічних межах знайшли відображення в працях українських учених Н.М.Бібік, М.С.Вашуленка, Н.С. Коваль, Я.П. Кодлюк, В. П. Тименка та ін.

Постановка завдання. Визначити та схарактеризувати тенденцї розвитку підручникотворення в початковій освіті у період
Urgency of the research. In the context of the creation of a new Ukrainian school, it is important to modernize the content of education, one of the means of implementing which was and remains a textbook. Therefore, the task of scientists and teacherspractitioners is to prepare a new generation of educational literature.

Target setting. The current educational transformations actualize the thorough study, comprehension and creative use of domestic historical and pedagogical experience, in particular the development of textbook creation in the primary education. In this context, scientific interest is aroused by the period of revival of the National School in Ukraine, which is characterized by a significant update of the content of primary education, the creation of a new generation of textbooks for younger schoolchildren.

Actual scientific researches and issues analysis. Various aspects of the development of textbook formation in primary education within the selected chronological limits are reflected in the works of Ukrainian scientists N. M. Bibik, M. S. Vashulenko, N. S. Koval, Ya. P. Kodlyuk, A. Ya.Savchenko, V. P. Timenko and others.

The research objective. Identify and characterize trends in the development of textbook creation in the primary education during the first 
першого десятиліття державної незалежності України (1991-2001) задля врахування попередніх надбань та уникнення помилок у процесі творення навчальної літератури для Нової украӥнської початкової школи.

Виклад основного матеріалу дослідження. Здійснений аналіз навчальних книжок, виданих у перше десятиліття незалежної України, дав змогу визначити такі тенденції $y$ розвитку підручникотворення в початковій освіті: перегляд змістового наповнення підручників з огляду на принципи дитиноцентризму, національної спрямованості, гуманізацї; розроблення нового покоління навчальної літератури українськими авторами; підготовка єдиних навчальних книжок для трирічної та чотирирічної початкової школи; створення нових типів підручників $i$ навчальних посібників - альтернативних, дворівневих, інтегрованих, загальнорозвивального характеру; запровадження ӥх апробації та проходження процедури "грифування". Поряд із позитивними тенденціями в розвитку підручникотворення в початковій освіті зазначимо й негативні: поглиблення проблеми видання навчальної літератури, вчасного забезпечення нею молодших школярів, підготовка навчальної літератури малопрофесійними авторами, повернення оплати за користування підручниками.

Висновки. Проаналізовані джерела дозволили не лише отримати нове історико-педагогічного знання, $a \breve{u}$ осмислити попередній досвід у процесі сучасного реформування освітнъої галузі, творення Нової украӥнсъкої початкової школи. Переконані, що пріоритетними засадами у розвитку підручникотворення в початковій освіті мають залишатися дитиноцентризм, національна спрямованість, гуманізація, варіативність, диференціація, що були започатковані та реалізовувалися у перше десятиліття державної незалежності Украйни. decade of State independence of Ukraine (1991-2001) to take into account previous achievements and avoid mistakes in the process of creating educational literature for the new Ukrainian primary school.

The statement of basic material. The analysis of educational books published in the first decade of independent Ukraine allowed us to determine the following trends in the development of textbook creation in primary education: revision of the content of textbooks taking into account the principles of child-centrism, National Orientation, humanization; development of a new generation of educational literature by Ukrainian authors; preparation of unified educational books for three-year and four-year primary schools; creation of new types of textbooks and manuals alternative, two-level, integrated, general development in nature; introduction of their testing and passing the "stamp" procedure. Along with positive trends in the development of textbook-making in primary education, we also note negative ones: deepening the problem of publishing educational literature, providing it to younger schoolchildren in a timely manner, preparing educational literature by low-professional authors, and returning payment for using textbooks.

Conchusions. The analyzed sources allowed not only to gain new historical and pedagogical knowledge, but also to comprehend previous experience in the process of modern reform of the educational sector, the creation of a new Ukrainian primary school. We are convinced that the priority principles in the development of textbook-making in primary education should remain childcentrism, National Orientation, humanization, variability, differentiation, which were started and implemented in the first decade of State independence of Ukraine. 
Освітній дискурс: збірник наукових праць, 27(10), 2020

Ключові слова: розвиток підручникотворення; початкова освіта; тенденцї; Украӥна.
Keywords: textbook creation; primary education; trends; Ukraine.

Актуальність теми дослідження. В умовах створення Нової української школи важливого значення набуває модернізація змісту освіти, одним із засобів реалізації якого був і залишається підручник. Відтак завданням науковців і педагогів-практиків $\epsilon$ підготовка навчальної літератури нового покоління, що сприятиме формуванню цілісної, всебічно розвиненої особистості із активною життєвою позицією, здатну змінювати навколишній світ, навчатися впродовж життя [10]. Особливої уваги в напрямі удосконалення змісту, структури потребують підручники для початкової школи, оскільки з них учні отримують перші усвідомлені знання про загальнолюдські цінності, завдяки ним у молодших школярів формуються бажання і вміння вчитися, виховуються моральні, естетичні якості, почуття громадянськості, патріотизму, національної свідомості тощо.

Постановка проблеми. Нинішні освітні трансформації актуалізують грунтовне вивчення, осмислення і творче використання вітчизняного історико-педагогічного досвіду, зокрема розвитку підручникотворення в початковій освіті. У такому контексті наукове зацікавлення викликає період відродження національної школи в Україні, характерними особливостями якого стало суттєве оновлення змісту початкової освіти, створення нового покоління підручників для молодших школярів.

Аналіз останніх досліджень і публікацій. Історіографічний аналіз показав, що проблема підручникотворення як одна із магістральних і водночас дискусійних завжди перебувала в полі зору дослідників. Різні аспекти розвитку підручникотворення в початковій освіті в обраних хронологічних межах знайшли відображення в працях українських учених Н. М. Бібік, М. С. Вашуленка, Н. С. Коваль, Я. П. Кодлюк, О. Я. Савченко, В. П. Тименка та ін.

Постановка завдання. На основі аналізу різних типів джерел визначити та схарактеризувати тенденції розвитку підручникотворення в початковій освіті у період першого десятиліття державної незалежності України (1991-2001) задля врахування попередніх надбань та уникнення помилок у процесі творення навчальної літератури для Нової української початкової школи.

Виклад основного матеріалу дослідження. 3-поміж багатьох проблем, які постали перед початковою освітою в перше десятиліття державної незалежності України, особлива роль відводилася модернізації змісту освіти. Адже саме зміст освіти, як зазначала О.Я. Савченко, "є своєрідною моделлю вимог суспільства до підготовки молодих поколінь до життя. У ньому в особливій формі відображається матеріальна та духовна культура людства" [18, с. 6].

Конструювання змісту початкової освіти грунтувалося на нових методологічних (демократизація, деполітизація, деідеологізація, національна спрямованість, дитиноцентризм, відповідність соціальним запитам суспільства) i дидактичних (варіативність, гуманітаризація, гуманізація, диференціація, інтеграція) засадах, що вимагало оновлення не лише навчальних планів і програм, а й навчальної літератури для 
молодших школярів. Як уже зазначалося у наших попередніх публікаціях [5, с. 284; 6, с. 283], перегляд змістового наповнення начальних книжок (букварів, читанок та підручників з мов) і підготовка їх до перевидання розпочалися ще в 1990 р. Так, за оновленими підручниками з читання (авт. Н.Ф. Скрипченко, О.Я. Савченко) молодші школярі мали змогу навчатися вже 3 1990/91 н. р. У читанках було збільшено кількість доступних для дітей цього віку творів українських письменників і поетів, посилено роль усної народної творчості - уведено чимало казок, народних пісень, прислів”їв, колисанок, щедрівок, колядок. Наприклад, у читанці для IV класу фольклорний матеріал представлено не лише наскрізно, а й згруповано у великий розділ “Усна народна творчість". Важливо, що в підручниках з читання було зменшено кількість текстів політичного та ідеологічного змісту. Декларативна поезія Н. Забіли, М. Познанської, М. Рильського замінювалася високохудожніми творами для дітей [1919; 20].

Однак оновити навчальну літературу в короткі терміни 3 урахуванням технологї їі видання було вкрай складно. Тому вчителям доводилося швидко реагувати на події життя, творчо використовувати чинні навчальні книжки, інші джерела, вчасно вносити корективи до змісту навчальних предметів [5, с. 281]. 31992 р. в "Інформаційному збірнику Міністерства освіти України” друкувалися переліки підручників і навчальних посібників, придатних до використання в закладах загальної середньої освіти, а також тих навчальних книжок, які через застарілість змістового наповнення підлягали вилученню зі шкільних фондів i освітнього процесу [11, с. 10-12; 12, с. 3-6].

Задля поліпшення підручникового забезпечення та підготовки принципово нового покоління навчальної літератури, яка відповідала б науковому і методичному рівням, укладалася на національній основі, була б більш досконалою за змістом та поліграфічним виконанням, у 1992 р. Міністерство освіти України ініціювало створення цільової комплексної програми “Навчальна книга". Вона передбачала розроблення нової навчальної літератури, навчальних комплектів; формування науково обгрунтованих вимог до підручників і навчальних посібників, їх типології, конструкції й технології видання [15, с. 3].

Завдяки зусиллям окремих авторів і авторських колективів у 1994 р. для початкових класів було перевидано фактично всі підручники [9Ошибка! Источник ссылки не найден., с. 102]. Окрім того, підручниковий фонд збагатився новими навчальними книжками 3 навчання грамоти - Материнка (авт. Д. С. Чередниченко); Букварик (авт. Д. В. Луцик, М. М. Проць, А. С. Савшак); Буквар (авт. М. М. Чорна, Д. І. Грабар); з читання - Ластівка, II кл., Біла хата, III кл., Писанка, IV кл. (авт. Оксана Верес); Золоте джерельце, II(I) кл., Чарівний струмок, III(II) кл., Чиста криниця, IV(III) кл. (авт. С. С. Жовнір-Коструба, Н. С. Жовнір-Іватьо, О.Д. Жовнір); 3 курсу “Навколишній світ” Віконечко, І кл. (авт. Н. М. Бібік, Н. С. Коваль); $з$ природознавства Природознавство, III(II) та IV(III) кл. (авт. Н. С. Коваль); 3 образотворчого мистецтва - Образотворче мистецтво, I-III кл. (авт. М. А. Кириченко) та ін.

Звернемо увагу, що відповідно до нової програми з математики, а також принципів відбору та структурування навчального матеріалу, 
відомим ученим-методистом М. В. Богдановичем укладено нові підручники з цього предмета. Істотною особливістю навчальних книжок стала їх дворівнева побудова [2]. Перший рівень передбачав обов'язкову математичну підготовку, яку мали набути всі учні. Зміст і обсяг відповідного матеріалу визначався навчальною програмою та був представлений в обов'язкових або першого рівня завданнях. Другий рівень - поглиблене вивчення предмета учнями, які мали математичні здібності й, відповідно, працювали у прискореному темпі, оволодіння ними позапрограмовим матеріалом. Завдання другого рівня або необов'язкові (позначалися зірочками) включали поширені програмові приклади й задачі, нестандартні завдання більш високого рівня складності та вправи 3 логічним навантаженням [3, c.26]. Тобто, новий дворівневий тип підручника дозволяв опановувати зміст навчального матеріалу “на різних ступенях деталізації”, здійснювати диференційований підхід у навчанні.

Нагадаємо, що 31986 р. до 2001 р. в Україні функціонували два типи початкової школи: трирічна (з початком вступу до неї у 7 років) та чотирирічна (з початком вступу - в 6 років). У 1990 р. вперше був підготовлений єдиний для цих типів шкіл підручник “Українська мова", IV(III) кл. (авт. Л. О. Варзацька, М. С. Вашуленко (ред.), О. І. Мельничайко,

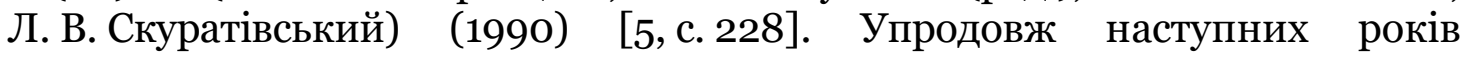
продовжено створення й видання єдиних підручників для трирічної та чотирирічної початкової школи, а саме: Читанка, III(II) кл. (авт. Н. Ф. Скрипченко, О. Я. Савченко); Читанка, IV(III) кл. (Н. Ф. Скрипченко, О. Я. Савченко, Н. Й. Волошина); Українська мова, III(II) кл. (авт. М. С. Вашуленко, О. І. Мельничайко); Українська мова, IV(III) кл. (авт. Л. О. Варзацька, М. С. Вашуленко, О. І. Мельничайко, Л. В. Скуратівський); Природознавство, III(II) та IV(III) кл. (авт. Н. С. Коваль) [12, с. 3-6].

Грунтування початкової освіти на демократичних засадах сприяло появі підручників 3 певного навчального предмета, підготовлених різними авторами, що уможливило функціонування паралельних або альтернативних навчальних книжок. Так, у 1995/96 н. р. Міністерством освіти України було запропоновано для використання в чотирирічній початковій школі 4 альтернативні букварі та 6 читанок, в трирічній -4 i 4 відповідно [12, с. 3-6].

Загалом навчальна література першої половини 90-х pp. ХХ ст. вирізнялася удосконаленою структурою, змістом, методичним апаратом, національною спрямованістю. Проаналізувавши низку читанок, простежуємо, що особливо виразно у них представлений образ Батьківщини. Так, у підручниках з читання, укладених провідними фахівцями у галузі початкової освіти - Н.Ф.Скрипченко та О. Я. Савченко, а також Н. Й. Волошиною (співавтор читанки для IV(III) класу), тема Батьківщини наскрізно розглянута в кожному класі 3 поступовим поглибленням і розширенням іiї змістового наповнення [2124]. Образ Батьківщини репрезентований у читанках, є синтезом “малої” і “великої” Батьківщини та їхніх семантичних меж - минулого і сучасності, окремих постатей і в цілому українського народу, що формуються у молодших школярів за допомогою усіх структурних компонентів підручника [4].

3 початку 90-х рр. ХХ ст. поширювалася тенденція щодо створення 
навчальної літератури не лише провідними фахівцями-методистами в галузі початкової освіти або за їхнього співавторства. 3'явилися нові прізвища авторів та авторські колективи. До процесу формування змісту початкової освіти, крім науковців, долучилися викладачі педагогічних навчальних закладів, учителі, методисти інститутів удосконалення вчителів, а також письменники, видавці та ін. Серед них були й такі, що мали досить абстрактне уявлення про зміст початкової освіти, не володіли знаннями про теорію підручникотворення. Тому, як зазначала О. Я. Савченко, особливої значущості набули проблеми підвищення якості навчальної літератури, створення механізму іiі надійного захисту від малопрофесійних і недостатньо сумлінних авторів [16, с. 2].

У зв'язку з дефіцитом паперу та з кон'юнктурних причин дедалі більше загострювалася проблема видання навчальної літератури: низка підручників не друкувалася, а з окремих найменувань зменшувалися наклади. Звичайно, така ситуація ускладнювала роботу учнів і вчителів та не сприяла якості освітнього процесу. Тому особлива увага Міністерства освіти України зверталася на раціональний розподіл навчальної літератури, закладання всіх підручників i навчальних посібників у бібліотечні фонди, організацію роз'яснювальної роботи серед учнів і батьків щодо їх збереження [5, с. 284].

Отже, характерними тенденціями у розвитку підручникотворення в початковій освіті упродовж першої половині 90-х рp. ХХ ст. стали: перегляд змістового наповнення підручників, їх перевидання 3 урахуваннях нових методологічних i дидактичних принципів конструювання змісту початкової освіти; поява нової навчальної літератури з навчання грамоти, читання, математики, природознавства, образотворчого мистецтва; підготовка єдиних навчальних книжок для трирічної та чотирирічної початкової школи; створення нових типів підручників - альтернативних i дворівневих, що розглядаємо як позитивні тенденції; водночас актуалізувалося питання про залучення фахівців до розроблення навчальної літератури, створення якісних підручників i навчальних посібників, вчасне забезпечення ними молодших школярів, що відносимо до низки негативних.

Наступний етап у модернізації змісту початкової освіти пов'язуємо з прийняттям у 1996 р. нового Закону України “Про освіту”, що активізував питання стандартизації змісту освіти. Упровадження державних стандартів в умовах варіативності тогочасної освітньої системи дозволяло забезпечити єдиний освітній простір у державі; визначити обов'язковий i достатній рівень загальноосвітньої підготовки молодших школярів, які навчалися у різних типах закладів освіти; відійти від предметоцентризму й представити зміст освіти цілісно, що, безперечно, вплинуло на розвиток підручникотворення. Паралельно із розробленням стандарту відбувалося оновленого чинного змісту початкової освіти (перехід до типових навчальних планів 3 інваріантною та варіативною частинами, уведення нових навчальних предметів і курсів суспільствознавчого та оздоровчого спрямування, розроблення нових варіативних програм) [5, с. 294].

Позитивною тенденцією другої половини 90-х рp. ХХ ст. стала поява нового покоління підручників, що репрезентували нове розуміння бази знань, новітні методики й технології навчання та засоби формування особистості. Складені як за чинними, так і за авторськими програмами, 
вони відрізнялися від традиційних добором навчального матеріалу, методичним апаратом, системою вправ і завдань, зорієнтованих на активізацію творчих здібностей молодших школярів, формування у них активної життєвої позиції. Навчальна література спрямовувалася на реалізацію принципів індивідуалізації та особистісної орієнтованості освітнього процесу, посилення розвивального ефекту змісту освіти [5, 291292].

Яскравим прикладом нового покоління навчальних книжок став навчальний посібник “Віконечко”, підготовлений завідувачкою лабораторії навчання i виховання молодших школярів Інституту педагогіки АПН України Н. М. Бібік спільно з науковим співробітником зазначеної лабораторії Н.С. Коваль, 3 навчального предмета “Ознайомлення з навколишнім". Цей оригінальний посібник поєднав у собі функції зошита й підручника та передбачав виконання молодшими школярами різноманітних практичних дій, творчих завдань. Наприклад, на його сторінках учням пропонувалося домалювати розпочате художником, дописати речення, придумати власний висновок тощо. Нестандартність навчального посібника простежується також у написанні текстів, зокрема автор нібито веде діалог з учнем, персоніфіковано звертається до нього [1]. Його поява, як і дворівневих підручників, про які згадувалося вище, стали ознакою створення навчальних книг на засадах дитиноцентризму, де на першому місці перебувала дитина з її інтересами й можливостями, а потім - зміст навчальної книги. Такий підхід, як зазначала О.Я. Савченко, став виявом особистісно орієнтованого навчання [17, с. 94]. Отже, у змісті навчальної літератури окреслився перехід від знаннєвої парадигми, домінантної в радянській час, до особистісно орієнтованої.

Зазначимо, що у 1998/99 н. р. перелік навчальних книжок для початкових класів шкіл з українською мовою навчання за нашими підрахунками склав 103 найменування (у цю кількість включено варіативні, експериментальні, пробні підручники та навчальні посібники). Важливо, що вони були підготовлені українськими авторами та видані або перевидані протягом 1996-1998 pр. Наведемо назви окремих підручників і навчальних посібників з переліку предметів, що входили до інваріантної частини: навчання грамоти - Буквар (авт. Н.Ф.Скрипченко, М. С. Вашуленко); читання - Первоцвіт, I кл. (3-річна), Читанка, II кл. (4річна), Читанка, III(II) кл. (авт. Н. Ф. Скрипченко, О. Я. Савченко), Читанка, IV(III) кл. (авт. Н. Ф. Скрипченко, О. Я. Савченко, Н. Й. Волошина); украӥнсъка мова - Рідна мова, І кл. (3-річна), Рідна мова, II кл. (4-річна) (авт. М. А. Білецька, М. С. Вашуленко), Рідна мова, III(II) кл. (авт. М. С. Вашуленко, О. І. Мельничайко), Рідна мова, IV(III) кл. (авт. Л. О. Варзацька, М. С. Вашуленко, О. І. Мельничайко, Л. В. Скуратівський); математика - Математика, I кл. (4-річна), Математика, I кл. (3річна), Математика, III(II) кл., Математика, IV(III) кл. (авт. М. В. Богданович); навколишній світ - Віконечко, I кл. (авт. Н. М. Бібік, Н. С. Коваль), Журавлик, II(I) кл. (авт. Н. М. Бібік, Л. С. Бондаренко, Н. С. Коваль); природознавство - Природознавство, III(II) кл., IV(III) кл. (авт. Н. С. Коваль, Л. К. Нарочна); трудове навчання Умілі руки, I кл., II кл., III кл., Трудове навчання, IV кл. (авт. I. T. Міщенко); образотворче мистецтво - Образотворче мистецтво, III(II) кл. 
(авт. М.А. Кириченко); охорона життя $i$ здоров'я - Охорона життя i здоров'я учнів, III(II) кл., IV(III) кл. (авт. Л. А. Мечник, О. Р. Гемзюк, I. I. Жаркова, Б. М. Терещук) та ін. [13, с. 3-9]. Тож 3 усіх предметів інваріантної частини типового навчального плану, за винятком музики, початкові класи були забезпечені навчальною літературою.

За даними Я. П. Кодлюк, значно збільшився перелік підручників і навчальних посібників з варіативної частини. Так, з'явилися навчальні книги з народознавства - Живиця, II(I) кл., Дивосвіт, III(II) кл., Перлина, IV(III) кл. (авт. Н. С. Жовнір-Іватьо, О. Д. Жовнір, Т. М. Коструба); 3 валеологї - Абетка здоров'я, I кл. (авт. В. І. Шахненко), Абетка здоров’я, III кл. (авт. М. С. Дубовис, О. Б. Качеров, Ю. О. Короп), Валеологія, IIIII(IV) кл. (авт. Антон Алатон) та ін. [9, с. 107].

Новаційною тенденцією у національному підручникотворенні стала поява інтегрованих підручників. Наприклад, у навчальних книгах “Художня праця” I кл. (4-річна), II кл. (4-річна), III кл. (4-річна), IV кл. (4річна), II(I) кл., III(II) кл., IV(III) кл. (авт. В. П. Тименко) органічно поєднувався зміст різних предметів (мова, природознавство, математика, музика, образотворче мистецтво тощо); у підручнику “Горішок”, I кл. (4річна) (авт. М. С. Вашуленко, Н. М. Бібік, Л. П. Кочіна) зінтегрувалися знання з навчання грамоти, математики та ознайомлення з навколишнім світом. Новим явищем стали i навчальні посібники загальнорозвивального спрямування "Барвистий клубок”, “Розвивай свої здібності", "Умій вчитися", підготовлені провідним фахівцем у галузі початкової освіти О. Я. Савченко [13, с. 3-9].

Як бачимо, розвиток підручникотворення в початковій освіті виходив на якісно новий рівень: формування на нових демократичних засадах; відхід від уніфікованості, панування єдиної методичної системи; розвиток творчої ініціативи тощо. Водночас навчальна література потребувала надійного захисту від суб'єктивізму, недостовірної інформації, від перевантаження надто ускладненим чи, навпаки, дріб'язковим матеріалом, від невідповідності вимогам навчальних планів i програм [7, c. 15-16].

Задля упередження цих негативних явищ у 1996 р. Міністерство освіти України запровадило процедуру грифування навчальних книжок. 3 цього часу в освітньому процесі мала використовуватися “затверджена”, “допущена" або "рекомендована" предметною комісією Науковометодичної ради Міністерства освіти України навчальна література $[14$, c. 21-22].

3 метою підвищення якості підручникотворення, а також з'ясування відповідності навчальних книжок вимогам державного стандарту, основним принципам навчання, віковим пізнавальним можливостям учнів 31998 р. Міністерством освіти України, Академією педагогічних наук України та за участі педагогів-практиків, працівників закладів освіти щорічно проводилася апробація навчальної літератури [8, с. 4]. Так, у 1999/2000 н. p. у початковій школі апробувалося 11 назв підручників i навчальних посібників, з них 7 було рекомендовано до видання як стабільні. Серед них підручник “Журавлятко”, II(I) кл. (авт. В. О. Науменко), що містив доступні, цікаві тексти, які сприяли розвитку спостережливості учнів, їхньому патріотичному та естетичному вихованню, формуванню екологічної культури, науковому світогляду. Позитивні відгуки практиків 
отримали також підручники “Художня праця”, I кл., II кл. (авт. В. П. Тименко), адже, розроблені на засадах розвивального навчання, вони відповідали принципам особистісно орієнтованої моделі навчання. Схвально оцінений був і навчально-методичний комплекс "Горішок" (складався з підручника, зошита в двох частинах і методичного посібника "Навчання грамоти, математики, ознайомлення з навколишнім світом за інтегрованим підручником “Горішок”) (авт. М. С. Вашуленко, Н. М. Бібік, Л. П. Кочіна), оскільки інтеграція навчального матеріалу, структура i логіка викладу відповідали вимогам сучасної дидактики, були актуальними у період переходу до навчання учнів з шести років. Успішно пройшли апробацію i навчальні посібники "Вчимося музики" (авт. В. М. Островський, М. В. Сидір). Їх комплексна структура дозволяла забезпечити проведення різних форм і видів роботи на уроках музики. Навчальні книжки містили пісенний матеріал для співу і музичних ігор, твори для слухання, відомості з нотної грамоти [75, с. 17-18].

Зазначимо, що в другій половині 90-х pp. XX ст. поглиблювалася проблема 3 виданням навчальної літератури через економічну кризу в країні. Ця ситуація змусила уряд зробити непопулярний, але вимушений крок: встановлення з 1996/97 н. р. оплати за користування підручниками у розмірі 20 \% від їх первинної вартості за весь навчальний рік. Проте і за таких умов не всі навчальні книжки вчасно потрапляли до закладів освіти, що негативно позначалося на організації освітнього процесу, рівні та якості знань учнів. Усе це створювало відчутну напругу i тривожну ситуацію серед учнів, учительської і батьківської громадськості. Тому виникла необхідність змінити існуючий порядок забезпечення школярів навчальною літературою. Кабінет Міністрів України ухвалив рішення про поступовий перехід 31 січня 1999 р. на вільний продаж підручників i навчальних посібників для учнів закладів загальної середньої освіти $[7$, c. 14].

Тож у другій половині 90-х рр. ХХ ст. розроблення державного стандарту та оновлення чинного змісту освіти зумовили підготовку нового покоління навчальної літератури, її апробацію та проходження процедури “грифування", створення нових типів навчальних книжок - інтегрованих, загальнорозвивального характеру та побудованих на засадах дитиноцентризму. Поряд 3 позитивною динамікою поглиблювалася проблема з виданням навчальної літератури, що змусило уряд повернути оплату за користування підручниками, а також розпочати їх вільний продаж.

Висновки з даного дослідження і перспективи подальших розвідок. Отже, одним із магістральних питань у період розбудови української національної початкової школи у 1991-2001 рр. стала модернізація змісту освіти, що виявилася у побудові його на нових методологічних і дидактичних засадах, а відтак у перегляді навчальних планів, програм, підручників і навчальних посібників. Здійснений аналіз навчальних книжок, виданих у перше десятиліття незалежної України, дав змогу визначити такі тенденції у розвитку підручникотворення в початковій освіті: перегляд змістового наповнення підручників з огляду на принципи дитиноцентризму, національної спрямованості, гуманізації; розроблення нового покоління навчальної літератури українськими авторами; підготовка єдиних навчальних книжок для трирічної та 
чотирирічної початкової школи; створення нових типів підручників i навчальних посібників - альтернативних, дворівневих, інтегрованих, загальнорозвивального характеру; запровадження їх апробації та проходження процедури “грифування". Поряд iз позитивними тенденціями в розвитку підручникотворення в початковій освіті зазначимо й негативні: поглиблення проблеми видання навчальної літератури, вчасного забезпечення нею молодших школярів, підготовка навчальної літератури малопрофесійними авторами, повернення оплати за користування підручниками.

Проаналізовані джерела дозволили не лише отримати нове історико-педагогічного знання, а й осмислити попередній досвід у процесі сучасного реформування освітньої галузі, творення Нової української початкової школи. Переконані, що пріоритетними засадами у розвитку підручникотворення в початковій освіті мають залишатися дитиноцентризм, національна спрямованість, гуманізація, варіативність, диференціація, що були започатковані та реалізовувалися у перше десятиліття державної незалежності України. Уважаємо, що до процесу створення навчальної літератури для молодших школярів мають залучатися фахівці, а іiі упровадженню в освітній процес має передувати апробація з подальшим моніторингом якості здійснених змін.

\section{Список використаних джерел:}

1. Бібік, НМ \& Коваль, НС 1996. Віконечко, Київ, 45 с.

2. Богданович, МВ 1991. Математика. Підручник для 2 кл. чотириріч. початкової шк. 4-те вид., перероб., Київ : Радянсъка школа, 208 с.

3. Богданович, МВ, Корчевська, ОП \& Ящишина ТП 1991. 'Як працювати за дворівневим підручником з математики', Початкова школа, № 5, с. 26-29.

4. Гавриленко, ТЛ 2016. 'Образ Батьківщини в підручниках з читання для молодших школярів у період відродження національної школи в Україні (90-ті рр. ХХ ст.)', Украӥнські педагоги про національно-патріотичне виховання : зб. матеріалів Всеукр. наук.-практ. семінару, Київ: ДНПБ Украӥни ім. В. О. Сухомлинсъкого, с. 56-57.

5. Гавриленко, ТЛ 2019. Розвиток початкової освіти в Украӥні у другій половині $X X$ - на початку XXI століття: історико-педагогічний аспект. Монографія, Київ : Фенікс, 384 с.

6. Гавриленко, ТЛ \& Кузьомко, ЛМ 2020. 'Конструювання змісту початкової освіти на нових методологічних i дидактичних принципах у період відродження національної школи в Україні (1991-1996)', Вісник Національного університету “Чернігівський колегіум”: Серія: Педагогічні науки, вип. 8 (164), Чернігів, с. 278-285.

7. Доповідна записка про результати апробації навчальної літератури у 1999/200о навчальному році, 2000. Інформаційний збірник Міністерства освіти України, № 19, с. 15-22.

8. Доповідна записка про результати апробації навчальної літератури у 2000/2001 навчальному році, 2001. Інформаційний збірник Міністерства освіти Украӥни, № 15, с. 4-15.

9. Кодлюк, ЯП 2006. Теорія і практика підручникотворення в початковій освіті, Підручник, Київ: Наш час, 368 с.

10. Нова украйнсъка школа : концептуальні засади реформування середньої школи, 2016. Схвалено рішенням колегії МОН України від 27.10.2016 р., Доступно: <https://mon.gov.ua/storage/app/media/zagalna\%20serednya/novaukrainska-shkola-compressed.pdf> [13 вересень 2020]. 
11. Перелік підручників і навчальних посібників, придатних для використання в загальноосвітніх школах України в 1992/1993 навчальному році, 1992. Інформаційний збірник Міністерства освіти Украӥни, № 14, с. 10-32.

12. Перелік підручників і навчальних посібників, придатних для використання в загальноосвітніх школах України в 1995/1996 навчальному році, 1995. Інформаційний збірник Міністерства освіти Украӥни, № 13, с. 3-12.

13. Перелік програм, підручників та навчальних посібників, рекомендованих Міністерством освіти України для використання в середніх закладах освіти в 1998/1999 навчальному році, 1998. Інформаційний збірник Міністерства освіти Украӥни, № 17/18, с. 3-49.

14. Положення про порядок підготовки, експертизи, апробації підручників, навчальних та навчально-методичних посібників, 1998. Інформаційний збірник Міністерства освіти України, № 2, с. 19-25.

15. Про поліпшення організації підготовки і видання книг i навчальнометодичної літератури для закладів освіти України, 1992. Інформаційний збірник Міністерства освіти України, № 23, с. 3-5.

16. Савченко, ОЯ 2000. 'Без якісного підручника шкільна освіти неможлива', Педагогічна газета, № 8, с. 2.

17. Савченко, ОЯ 2012. Дидактика початкової освіти. Підручник, Київ : Грамота, 504 с.

18. Савченко, ОЯ 1996. 'Реформування змісту початкової освіти', Початкова школа, № 1, с. 4-8.

19. Скрипченко, НФ \& Савченко, ОЯ 1990. Читанка. Підручник для 1 кл. триріч. початкової шк., Київ : Радянсъка школа, 240 с.

20. Скрипченко, НФ \& Савченко, ОЯ 1990. Читанка. Підручник для 3 кл. чотириріч. початкової шк. 3-те вид., Київ : Радянсъка школа, 336 с.

21. Скрипченко, НФ \& Савченко, ОЯ 1992. Читанка. Підручник для 1 кл. триріч. початкової шк. 2-ге вид., перероб., Київ : Радянсъка школа, 223 с.

22. Скрипченко, НФ \& Савченко, ОЯ 1993. Читанка. Підручник для 2 кл. чотириріч. початкової шк., Київ : Освіта, 224 с.

23. Скрипченко, НФ \& Савченко, ОЯ 1998. Читанка. Підручник для 3 кл. чотириріч. і 2 кл. триріч. початкової шк. 8-ме вид., Київ : Освіта, 336 с.

24. Скрипченко, НФ, Савченко, ОЯ \& Волошина, НЙ 200о. Читанка. Підручник для 4 кл. чотириріч. і 3 кл. триріч. початкової шк. 6-те вид., Київ : Oсвіта, $228 \mathrm{c}$.

\section{References:}

1. Bibik, NM \& Koval, NS 1996. Vikonechko (The Small Window), Kiyiv, 45 s.

2. Bogdanovich, MV 1991. Matematika (Mathematics). Pidruchnik dlya $2 \mathrm{kl}$. chotiririch. pochatkovoyi shk. 4-te vid., pererob., Kiyiv : Radyanska shkola, $208 \mathrm{~s}$.

3. Bogdanovich, MV, Korchevska, OP \& Yashishina TP 1991. 'Yak pracyuvati za dvorivnevim pidruchnikom z matematiki (How to work on a two-level textbook in mathematics')', Pochatkova shkola, № 5, s. 2629.

4. Gavrilenko, TL 2016. 'Obraz Batkivshini v pidruchnikah z chitannya dlya molodshih shkolyariv u period vidrodzhennya nacionalnoyi shkoli v Ukrayini (90 ti rr. XX st.) (The image of the Motherland in reading textbooks for junior high school students during the revival of the national school in Ukraine (90s of the twentieth century))', Ukrayinski pedagogi pro nacionalno-patriotichne vihovannya : zb. materialiv Vseukr. nauk.-prakt. seminaru, Kiyiv: DNPB Ukrayini im. V. O. Suhomlinskogo, s. 56-57.

5. Gavrilenko, TL 2019. Rozvitok pochatkovoyi osviti $v$ Ukrayini u drugij polovini $X X$ - na pochatku XXI stolittya: istoriko-pedagogichnij aspekt (Development of primary education in Ukraine in the second half of the XX - early XXI century: historical and pedagogical aspect). Monografiya, Kiyiv : Feniks, $384 \mathrm{s.}$ 
6. Gavrilenko, TL \& Kuzomko, LM 2020. 'Konstruyuvannya zmistu pochatkovoyi osviti na novih metodologichnih i didaktichnih principah u period vidrodzhennya nacionalnoyi shkoli v Ukrayini (1991-1996) (Constructing the content of primary education on new methodological and didactic principles during the revival of the national school in Ukraine (1991-1996))', Visnik Nacionalnogo universitetu “Chernigivskij kolegium”: Seriya: Pedagogichni nauki, vip. 8 (164), Chernigiv, s. 278-285.

7. Dopovidna zapiska pro rezultati aprobaciyi navchalnoyi literaturi u 1999/2000 navchalnomu roci (Report on the results of approbation of educational literature in the 1999/2000 academic year), 2000. Informacijnij zbirnik Ministerstva osviti Ukrayini, № 19, s. 15-22.

8. Dopovidna zapiska pro rezultati aprobaciyi navchalnoyi literaturi u 2000/2001 navchalnomu roci (Report on the results of approbation of educational literature in the 2000/2001 academic year), 2001. Informacijnij zbirnik Ministerstva osviti Ukrayini, № 15, s. 4-15.

9. Kodlyuk, YaP 2006. Teoriya i praktika pidruchnikotvorennya v pochatkovij osviti (Theory and practice of textbook creation in primary education). Pidruchnik, Kiyiv: Nash chas, $368 \mathrm{c}$.

10. Nova ukrayinska shkola : konceptualni zasadi reformuvannya serednoyi shkoli (New Ukrainian school: conceptual principles of secondary school reform), 2016. Shvaleno rishennyam kolegiyi MON Ukrayini vid 27.10.2016 r., Dostupno: <https://mon.gov.ua/storage/app/media/zagalna\%2oserednya/nova-ukrainskashkola-compressed.pdf $>$ [13 Veresen 2020].

11. Perelik pidruchnikiv $\mathrm{i}$ navchalnih posibnikiv, pridatnih dlya vikoristannya $\mathrm{v}$ zagalnoosvitnih shkolah Ukrayini v 1992/1993 navchalnomu roci (List of textbooks and manuals suitable for use in secondary schools of Ukraine in the 1992/1993 academic year), 1992. Informacijnij zbirnik Ministerstva osviti Ukrayini, № 14, s. $10-32$.

12. Perelik pidruchnikiv i navchalnih posibnikiv, pridatnih dlya vikoristannya $\mathrm{v}$ zagalnoosvitnih shkolah Ukrayini v 1995/1996 navchalnomu roci (List of textbooks and manuals suitable for use in secondary schools of Ukraine in the 1995/1996 academic year), 1995. Informacijnij zbirnik Ministerstva osviti Ukrayini, № 13, s. 3-12.

13. Perelik program, pidruchnikiv ta navchalnih posibnikiv, rekomendovanih Ministerstvom osviti Ukrayini dlya vikoristannya v serednih zakladah osviti v 1998/1999 navchalnomu roci (List of programs, textbooks and manuals recommended by the Ministry of Education of Ukraine for use in secondary schools in the 1998/1999 academic year), 1998. Informacijnij zbirnik Ministerstva osviti Ukrayini, № 17/18, s. 3-49.

14. Polozhennya pro poryadok pidgotovki, ekspertizi, aprobaciyi pidruchnikiv, navchalnih ta navchalno-metodichnih posibnikiv (Regulations on the procedure for preparation, examination, testing of textbooks, training and teaching aids), 1998. Informacijnij zbirnik Ministerstva osviti Ukrayini, № 2, s. 19-25.

15. Pro polipshennya organizaciyi pidgotovki i vidannya knig i navchalnometodichnoyi literaturi dlya zakladiv osviti Ukrayini (On improving the organization of preparation and publication of books and educational and methodical literature for educational institutions of Ukraine), 1992. Informacijnij zbirnik Ministerstva osviti Ukrayini, № 23, s. 3-5.

16. Savchenko, OYa 2000. 'Bez yakisnogo pidruchnika shkilna osviti nemozhliva (Without a quality textbook school education is impossible)', Pedagogichna gazeta, № 8, s. 2.

17. Savchenko, OYa 2012. Didaktika pochatkovoyi osviti (Didactics of primary education). Pidruchnik, Kiyiv : Gramota, 504 s.

18. Savchenko, OYa 1996. 'Reformuvannya zmistu pochatkovoyi osviti (Reforming the content of primary education)', Pochatkova shkola, № 1, s. 4-8. 


\section{Освітній дискурс: збірник наукових праць, 27(10), 2020}

19. Skripchenko, NF \& Savchenko, OYa 1990. Chitanka (Reader). Pidruchnik dlya 1 kl. tririch. pochatkovoyi shk., Kiyiv : Radyanska shkola, $240 \mathrm{s.}$

20. Skripchenko, NF \& Savchenko, OYa 1990. Chitanka (Reader). Pidruchnik dlya 3 kl. chotiririch. pochatkovoyi shk. 3-te vid., Kiyiv : Radyanska shkola, $336 \mathrm{~s}$.

21. Skripchenko, NF \& Savchenko, OYa 1992. Chitanka (Reader). Pidruchnik dlya 1 kl. tririch. pochatkovoyi shk. 2-ge vid., pererob., Kiyiv : Radyanska shkola, $223 \mathrm{s.}$

22. Skripchenko, NF \& Savchenko, OYa 1993. Chitanka (Reader). Pidruchnik dlya 2 kl. chotiririch. pochatkovoyi shk., Kiyiv : Osvita, 224 s.

23. Skripchenko, NF \& Savchenko, OYa 1998. Chitanka (Reader). Pidruchnik dlya 3 kl. chotiririch. i 2 kl. tririch. pochatkovoyi shk. 8-me vid., Kiyiv : Osvita, 336 s.

24. Skripchenko, NF, Savchenko, OYa \& Voloshina, NJ 2000. Chitanka (Reader). Pidruchnik dlya $4 \mathrm{kl}$. chotiririch. i 3 kl. tririch. pochatkovoyi shk. 6-te vid., Kiyiv : Osvita, 228 s. 